ACTA MYCOLOGICA

Vol. 44 (2): 275-282

2009
Dedicated to Professor Krystyna Czyżewska

in honour of 40 years of her scientific activity

\title{
New records of lichens from the Polish uplands
}

\author{
ANNA ŁUBEK \\ Institute of Biology, Jan Kochanowski University, Świętokrzyska 15 \\ PL-25-406 Kielce, anna.lubek@ujk.kielce.pl
}

Lubek A.: New records of lichens from the Polish uplands. Acta Mycol. 44 (2): 275-282, 2009.

Five lichen species: Bacidia pycnidiata, Fellhanera gyrophorica, Leucocarpia biatorella, Parmotrema perlatum and Punctelia ulophylla, are presented. Bacidia pycnidiata, Leucocarpia biatorella, Punctelia ulophylla are new to Central Poland. Bacidia pycnidiata is reported from Poland for the third time.

Key words: rare lichens, new sites, Central Poland

\section{INTRODUCTION}

Studies on lichens in the Świętokrzyskie Mts. (Kielce and the Chęcińsko-Kielecki Landscape Park) and adjoining sites (the Oleszno nature reserve in the Przedborski Landscape Park) (Fig. 1) have been conducted in recent years. A few interesting species of lichens that are very rare in Poland were found. Those are: Bacidia pycnidiata, Fellhanera gyrophorica, Leucocarpia biatorella, Parmotrema perlatum and Punctelia ulophylla. Two of them, Bacidia pycnidiata and Fellhanera gyrophorica, have lately been described to science. Intensive lichenological research carried out in different regions of Poland, including the Świętokrzyskie Mts., provides new data on the occurrence of these lichens as each new and verified site is very important for the knowledge on habitat preferences and the material distribution of the species in Poland. The main goal of this work is to provide the most up-to-date information on the above species. 


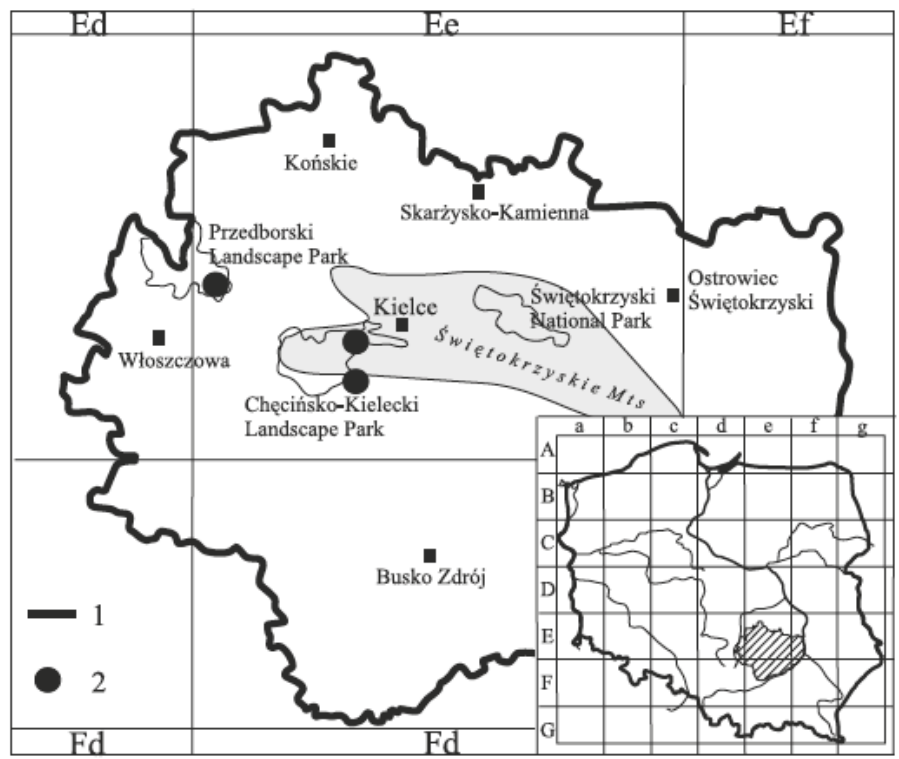

Fig. 1. Investigated area:

1 - boundary of Świętokrzyskie Province, 2 - examined sites.

\section{MATERIAL AND METHODS}

Lichens were collected in 2007 and 2008 at six sites in the Przedborski Landscape Park and the Chęcińsko-Kielecki Landscape Park located in Ee 60, 73, 83 ATPOL grid square system (Fig. 1) (acc. to Cieśliński, Fałtynowicz 1993). The material was analyzed with standard morphological and anatomical methods.

The nomenclature of the species follows Faltynowicz (2003; see also Diederich et al. 2009), that of Bacidia pycnidiata - Czarnota and Coppins (2006) and Punctelia ulophylla - van Herk and Aptroot (2000). The specimens are deposited in the herbarium of the Jan Kochanowski University (KTC).

Abbreviations: PrzLP - the Przedborski Landscape Park, Ch-KLP - the Chęcińsko-Kielecki Landscape Park.

\section{LIST OF SPECIES}

Bacidia pycnidiata Czarnota \& Coppins, Lichenologist 38 (5): 407 (2006).

For the description of the species see Czarnota and Coppins (2006). The specimens do not have apothecia but very well shaped whitish-cream pycnidia with a typical long ostiolar neck and filiform, transversely septate conidia. $B$. pycnidiata grows on corticolous bryophytes and directly on bark at the base of deciduous trees. 
Distribution. Europe: Belgium, the Czech Republic, Estonia (Czarnota, Coppins 2006; Suija et al. 2007; Diederich et al. 2009).

In Poland, B. pycnidiata is known from mountainous regions: the Western Beskidy Mts. and the Pogórze Środkowobeskidzkie Foothills (Czarnota, Coppins 2006).

SPECIMENS EXAMINED. ATPOL grid square Ee $\mathbf{6 0}$ - PrzLP, near the Oleszno nature reserve, forest section no 79, on bryophytes and on a trunk of Fraxinus excelsior, 7 Feb. 2008 (KTC 8157). Ee 73 - Ch-KLP, the Pasmo Zgórskie Range, at the edge of the forest near the village of Zagórze, on a trunk of Quercus sp., 9 Aug. 2007 (KTC 7994).

Note. The species is reported as new to the Świętokrzyskie Mts. This is the third site in Poland.

Fellhanera gyrophorica Sérus., Coppins, Diederich \& Scheid., Lichenologist 33 (4): 285 (2001).

For the description of the species see Sérusiaux et al. (2001) and Sparrius (2002). F. gyrophorica is usually sterile and produces only large brown pycnidia reacting C+ red. Apothecia were found only once in the material collected from the Puszcza Białowieska forest (Sparrius 2002). The specimens from the Przedborski Landscape Park have pycnidia only. F. gyrophorica grows on tree bark or invades corticolous mosses and liverworts in old-growth forests.

Distribution. Europe: Austria, Luxembourg, Switzerland, Estonia, Lithuania, Belarus, Ukraine and Slovakia (Sérusiaux et al. 2001; Motiejūnaitė, Prigodina-Lukošienè 2002; Motiejūnaitė et al. 2003; Golubkov, Kukwa 2006; Pišút et al. 2007).

F. gyrophorica is very rare in Poland. It is known from Northern Poland: Gdańsk Pomerania (Kukwa 2006/2007), the Wysoczyzna Elbląska high plain (Szymczyk, Kukwa 2008) and North-East Poland: the Puszcza Białowieska forest (Czyżewska et al. 2001; Sparrius 2002; 2003), the Puszcza Borecka forest (Sérusiaux et al. 2001), the Budzisk nature reserve in the Puszcza Knyszyńska forest (Czyżewska et al. 2002), the Biebrza National Park (Czyżewska et al. 2005). In Central Poland it has been reported from the Puszcza Kozienicka forest (Cieśliński 2007) and the Spała nature reserve in the Puszcza Pilicka forest (Motiejūnaitè, Czyżewska 2008).

SPECIMENS EXAMINED. Ee 60 - PrzLP, near the Oleszno nature reserve, forest section no 73, on a trunk of Fraxinus excelsior, 11 Mar. 2008 (KTC 8018), the Oleszno nature reserve, forest section no 54, on a trunk of Quercus sp., 25 May 2008 (KTC 8025).

Leucocarpia biatorella (Arnold) Vĕzda, Herzogia 1: 192 (1969).

Syn. Microglaena biatorella Arnold, Microthelia biatorella (Arnold) Dalla Torre \& Sarnth.

For the description of the species see Purvis et al. (1992). L. biatorella grows on soil and calcareous stones associated with mosses. It is similar to Chromatochlamys muscorum which has larger ascospores 2-4 per ascus, and Polyblastia gelatinosa which has black perithecia and grows on bryophytes. The specimen from the Chęcińsko-Kielecki Landscape Park has a pale granular-verrucose thallus and immersed perithecia with a flat yellow-pinkish ostiolar region. Ascospores are eight per ascus, hyaline and muriform, 28-36 × 11-15 $\mu \mathrm{m}$.

Distribution. North America: continental United States and Canada (Esslinger 2008); Europe: Great Britain and Ireland, Sweden and Finland (Santesson 1993; Vitikainen et al. 1997; Coppins 2002), Asia: Mongolia (Biazrov 2009).

L. biatorella has so far been reported from Southern Poland - the Western Carpathians Mts. (Olech 1999 and literature cited in: Flakus 2007), near the town 
of Olkusz (Kiszka, Kościelniak 2006), the Śnieżnik Massif and the Bialskie Mts. (Szczepańska 2008).

Specimen examined. Ee 83 - Ch-KLP, the Pasmo Zelejowskie range, N slope of Wiśniowa Mt., on stones in shady and wet places, 16 Aug. 2007 (KTC 7995).

Note. Species reported as new to Central Poland and the Świętokrzyskie Mts.

Parmotrema perlatum (Huds.) M. Choisy, Bull. mens. Soc. linn. Lyon 21: 174 (1952).

Syn. P. chinense (Osbeck) Hale \& Ahti, Parmelia perlata (Huds.) Ach., P. trichotera Hue.

For the description of the species see Purvis et al. (1992). P. perlatum grows on well-lit, neutral to somewhat acid-barked, broad-leaved trees and also frequently on siliceous rocks and walls. The species is sensitive to the mean $\mathrm{SO}_{2}$ level in the atmosphere.

The species grows only in the best parts of old-growth forests according to Motyka (1960). The specimen collected in the Przedborski Landscape Park has a very well developed thallus with marginal soralia and cilia. It was observed in small groups only on one tree in a sunny place.

Distribution. Europe: Great Britain and Ireland, Denmark, Norway, Germany, the Czech Republic, Romania (Santesson 1993; Vězda, Liška 1999; Scholz 2000; Coppins 2002; Søchting, Alstrup 2007; Ciurchea 2009); Asia: China (Checklist of lichens and lichenicolous fungi of Yunnan), Japan (Kurokawa 2003), Thailand (Wolseley et al. 2002), Turkey (Checklist of lichens and lichenicolous fungi of Turkey); New Zealand (Galloway 2007); North America: continental United States and Canada (Tucker, Ryan 2006; Esslinger 2008); South America: Argentina (Checklist of lichens and lichenicolous fungi of Argentina); Africa: Algeria (Checklist of lichens and lichenicolous fungi of Algeria), Tanzania (Checklist of lichens and lichenicolous fungi of Tanzania); Australia (Elix, McCarthy 2008).

It has been reported in Poland from the Wyżyna Lubelska upland, the Kotlina Sandomierska basin, the Gorce Mts., the Beskid Sądecki Mts. and the Bieszczady Mts. in the $19^{\text {th }}$ and the $20^{\text {th }}$-century literature (Motyka 1960; Sulma, Fałtynowicz 1988; Bielczyk 1997; see also Fałtynowicz 2003). Lately it has only been reported from the Polish Eastern Carpathians (Kiszka, Kościelniak 1998; Kościelniak 2008).

Specimen EXAmined. Ee 60 - PrzLP, near the Oleszno nature reserve, forest section no 73, on a trunk of Fraxinus excelsior, 11 Mar. 2008, det. M. Kukwa (KTC 8004).

Note. P. perlatum is an endangered species in Poland (CR) (Cieśliński et al. 2003).

Punctelia ulophylla (Ach.) van Herk \& Aptroot, Lichenologist 32 (3): 239 (2000).

Syn. P. subrudecta var. ulophylla (Ach.) Harm.

For the description of the species see van Herk and Aptroot (2000). P. ulophylla is known only to be corticolous. It grows on a wide variety of trees.

P. ulophylla can be mistaken for P. subrudecta. Extreme margins of the thallus of P. ulophylla are dull brownish and pruinose. Secondary lobes have dense marginal soredia. Extreme margins of the thallus of $P$. subrudecta are dark brown, glossy and not pruinose, marginal soredia are absent and only soredia laminal are present (van Herk, Aptroot 2000). Thalli of Punctelia ulophylla from the Przedborski Landscape Park were recorded abundantly on thick branches.

Distribution. Europe: Great Britain, Belgium, France, the Netherlands, Germany, Poland, Slovakia, Switzerland (van Herk, Aptroot 2000; Coppins 2002), Northern America (Tucker, Ryan 2006). 
The species has been reported in Poland from the Sudetes Mts., the Western Bieszczady Mts. (Sulma, Fałtynowicz 1988; see also Fałtynowicz 2003 and van Herk, Aptroot 2000).

SPeCimEnS EXAMINED. Ee 60 - PrzLP, near the Oleszno nature reserve, forest section no 79, in the crown of Fraxinus excelsior, 7 Feb. 2008, det. M. Kukwa (KTC 8003, 8006), forest section no 73, in the crown of Fraxinus excelsior, 7 Feb., 11 Mar. 2008, det. M. Kukwa (KTC 8086, 8005) and the Oleszno nature reserve, forest section no 60, in the crown of Fraxinus excelsior, 25 May 2008 (KTC 8054).

Note. Species new to Central Poland.

\section{CONCLUSIONS}

1. Of the lichens collected, Fellhanera gyrophorica is especially noteworthy. It is connected with old-growth forests and its richest occurrence was observed in big forest complexes such as the Puszcza Białowieska forest, the Puszcza Borecka forest, the Puszcza Knyszyńska forest, the Puszcza Pilicka forest or the Puszcza Kozienicka forest. The occurrence of $F$. gyrophorica in the Oleszno nature reserve and in its vicinity could result from good habitat conditions, especially a high level of air humidity. A natural mixed family tree-stand, permanently waterlogged in some places, with a considerable participation of Alnus glutinosa and Fraxinus excelsior, is protected within the Oleszno nature reserve. Less accessible areas are unaffected by human activity and are also a refuge to other interesting lichen species, such as Parmotrema perlatum.

2. It is very interesting that Leucocarpia biatorella, which grows mostly in the high part of mountains, has been recorded from the Świętokrzyskie Mts. The occurrence of the species here may be connected with the presence of metals in the substrate, such as zinc, lead, iron and limestone, or its tolerance to heavy metals in the substrate is high (cf. Kiszka, Kościelniak 2006). Limestone, marble from Chęciny and sparite were extracted in the Pasmo Zalejowskie range in the past and copper, lead and silver ores were found in the neighbouring Pasmo Chęcińskie range where the species was observed. The location of $L$. biatorella may be situated at the site of previous vein extraction. This is supported by the presence of many wells of different depth in the ground around which numerous rock blocks covered with Bryophytes occur. Beechwood that grows at the site makes it shaded and quite dump. It is another anthropogenic site of L. biatorella in Poland apart from the Wyżyna Śląska upland. Lichenological research conducted in other parts of the Świętokrzyskie Mts. where limestone occurs did not reveal the presence of this species. Further research is required to complete ecological requirements of the species and to describe the species accurately.

Acknowledgements. I would like to thank Prof. Stanisław Cieśliński (Jan Kochanowski University, Kielce), Dr. hab. Paweł Czarnota (Scientific Laboratory, the Gorce National Park) and Dr. Martin Kukwa (University of Gdańsk) for determining or revising the determination of some taxa. Thanks are also due the anonymous reviewer for valuable comments and remarks. The work was supported in part by Jan Kochanowski University grant no 221/W/08. 


\section{REFERENCES}

Biazrov L. G. 2009. Checklist of the Mongolian lichens. Version 6. Available at http://www.sevin.ru/laboratories_eng/biazrov_mong.html [date of exploration: 2 June 2009].

Bielczyk U. 1997. Materiały do flory porostów Tatr ze zbiorów Muzeum Tatrzańskiego. Fragm. Florist. Geobot. Polonica 4: 329-343.

Checklist of lichens and lichenicolous fungi of Algeria. Available at http://www.biologie.uni-hamburg.de/ checklists/lichens/africa/algeria_1.htm [date of exploration: 2 June 2009].

Checklist of lichens and lichenicolous fungi of Argentina. Available at http://www.biologie.uni-hamburg. de/checklists/lichens/south-america/argentina_l.htm [date of exploration: 2 June 2009].

Checklist of lichens and lichenicolous fungi of Tanzania. Available at http://www.biologie.uni-hamburg. de/checklists/lichens/africa/tanzania_l.htm [date of exploration: 2 June 2009].

Checklist of lichens and lichenicolous fungi of Turkey. Available at http://www.biologie.uni-hamburg.de/ checklists/lichens/middle-east/turkey_l.htm [date of exploration: 2 June 2009].

Checklist of lichens and lichenicolous fungi of Yunnan (China). Available at http://www.biologie.unihamburg.de/checklists/lichens/asia/china_yunnan_l.htm [date of exploration: 2 June 2009].

Cieśliński S. 2007. Stan bioty porostów w wybranych rezerwatach w Puszczy Kozienickiej. Parki nar. Rez. Przyr. 26 (3): 3-21.

Cieśliński S., Czyżewska K., Fabiszewski J. 2003. Czerwona lista porostów wymarłych i zagrożonych w Polsce. Monogr. Bot. 91: 13-49.

Cieśliński S., Fałtynowicz W. 1993. Note from editors. In: S. Cieśliński, W. Fałtynowicz (eds.), Atlas of the geographical distribution of lichens in Poland 1, 7-8. W. Szafer Institute of Botany, Polish Academy of Sciences, Kraków.

Ciurchea M. 2009. Checklist of lichens and lichenicolous fungi of Romania. Version 2009. Available at http://www.biologie.uni-hamburg.de/checklists/lichens/europe/romania_l.htm [date of exploration: 2 June 2009].

Coppins B. J. 2002. Checklist of lichens of Great Britain and Ireland. London. British Lichen Society, London. Available at http://www.thebls.org.uk/checklist.html [date of exploration: 2 June 2009].

Czarnota P., Coppins B. J. 2006. A new Bacidia with long-necked pycnidia from Central Europe. Lichenologist 38 (5): 407-410.

Czyżewska K., Motiejūnaitė J., Cieśliński S. 2001. Species of lichenized and allied fungi new to Białowieża Large Forest (NE Poland). Acta Mycol. 36 (1): 13-19.

Czyżewska K., Motiejūnaitė J., Cieśliński S. 2005. New and noteworthy species of lichens and allied fungi from North-Eastern Poland. Acta Mycol. 40 (2): 277-291.

Czyżewska K., Cieśliński S., Motiejūnaitè J., Kolanko K. 2002. The Budzisk nature reserve as a biocentre of lichen diversity in the Knyszyńska Large Forest (NE Poland). Acta Mycol. 37 (1/2): 77-92.

Diederich P., Ertz D., Stapper N., Sérusiaux E., van den Broeck D., van den Boom P., Ries C. 2009. The lichens and lichenicolous fungi of Belgium, Luxembourg and northern France. URL: http://www. lichenology.info [date of exploration: 2 June 2009].

Elix J. A., McCarthy P. M. 2008. Checklist of Pacific Island Lichens. Australian Biological Resources Study, Canberra. Version 21 August 2008. Available at http://www.anbg.gov.au/abrs/lichenlist/PACIFIC_introduction.html [date of exploration: 2 June 2009].

Esslinger T. L. 2008. A cumulative checklist for the lichen-forming, lichenicolous and allied fungi of the continental United States and Canada. North Dakota State University. Fargo, North Dakota. Available at http://www.ndsu.nodak.edu/instruct/esslinge/chcklst/chcklst7.htm [date of exploration: 2 June 2009].

Fałtynowicz W. 2003. The lichens, lichenicolous and allied fungi of Poland. An annotated checklist. W. Szafer Institute of Botany, Polish Academy of Sciences, Kraków, 435 pp.

Flakus A. 2007. Lichenized and lichenicolous fungi from mylonized areas of the subnival belt in the Tatra Mountains (Western Carpathians). Ann. Bot. Fennici 44: 427-449.

Galloway D. J. 2007. Flora of New Zealand, Lichens - Revised Second Edition. Available at http:// floraseries.landcareresearch.co.nz/pages/TaxonIndex.aspx?id=_15ba8bad-870c-4351-9bae079c16581caf\&fileName $=$ Lichen\%20Ed2\%20Pan-Z.xml [date of exploration: 2 June 2009].

Golubkov V. V., Kukwa M. 2006. A contribution to the lichen biota of Belarus. Acta Mycol. 41 (1): 155164. 
Herk van K., Aptroot A. 2000. The sorediate Punctelia species with lecanoric acid in Europe. Lichenologist 32 (3): 233-246.

Kiszka J., Kościelniak R. 1998. The flora of lichens in the Polish Eastern Carpathians. (In:) S. Kondratyuk, B. Coppins (eds). Lobarion lichens as indicators of primeval forests of the Eastern Carpathians (Darwin International Workshop, 25-30 May 1998, Kostrino, Ukraine). Kostrino, 81-101.

Kiszka J., Kościelniak R. 2006. Localities of the high-mountain species Leucocarpia biatorella in the Silesian Upland (sourthern Poland). (In:) A. Lackovičova, A. Guttová, E. Lisická, P. Lizoň (eds). Central European lichens - diversity and threat. Mycotaxon Ltd., Ithaca: 325-330.

Kościelniak R. 2008. Nowe i rzadkie gatunki porostów Lichenes w Bieszczadzkim Parku Narodowym i jego otulinie. Część X. Roczniki Bieszczadzkie 16: 253-258.

Kukwa M. 2006 (2007). Nowe stanowiska rzadkich i interesujących porostów na Pomorzu Gdańskim. Część III. Acta Bot. Cassub. 6: 141-152.

Kurokawa S. 2003. Checklist of Japanese Lichens. National Science Museum, Tokyo. 128 pp. Available at http://home.hiroshima-u.ac.jp/lichen/cklist.htm\#P [date of exploration: 2 June 2009].

Motiejūnaitė J., Czyżewska K. 2008. Additions to the biota of lichens and lichenicolous fungi of Poland with note on Lecania prasinoides in Eastern and Central Europe. Polish Bot. J. 53 (2): 155-162.

Motiejūnaitė J., Prigodina-Lukošienė I. 2002. Chaenothecopsis rubescens new to Lithuania and Fellhanera gyrophorica new to Estonia. Graphis Scripta 13: 43-44.

Motiejūnaitė J., Czyżewska K., Cieśliński S. 2004. Lichens - indicators of old-growth forests in biocentres of Lithuania and North-East Poland. Botanica Lithuanica 10 (1): 59-74.

Motiejūnaitė J., Kukwa M., Czarnota P., Prigodina-Lukošienė I., Himelbrant D., Kuznetsova E., Kowalewska A. 2003. Lichens and allied fungi collected during the 15th symposium of Baltic Mycologists and Lichenologists in Birštonas, Lithuania. Botanica Lithuanica 9 (2): 109-119.

Motyka J. 1960. Porosty. (Lichenes). 5.1. Parmeliaceae. Flora polska. Rośliny zarodnikowe Polski i ziem ościennych. PWN, Warszawa, 274 pp.

Olech M. 1999. Leucocarpia biatorella (Arnold) Vĕzda. In: Cieśliński S., Fałtynowicz W. (eds.), Atlas of the geographical distribution of lichens in Poland 2. W. Szafer Institute of Botany, Polish Academy of Sciences, Kraków: 35-37.

Pišút I., Lackovičová A., Guttová A., Palice Z. 2007. New lichen records from Bukovské vrchy Mts (NE Slovakia). Acta Mycol. 42 (2): 267-280.

Purvis O. A. W., Coppins B. J., Hawksworth D. L., James P. W., Moore D. M. 1992. The lichen flora of Great Britain and Ireland. Natural History Museum Publications in association with The British Lichen Society, 710 pp.

Santesson R. 1993. The lichens and lichenicolous fungi of Sweden and Norway. SBT - föörlaget, Lund.

Sérusiaux E., Coppins B. J., Diederich P., Scheidegger C. 2001. Fellhanera gyrophorica, a new European species with conspicuous pycnidia. Lichenologist 33 (4): 285-289.

Scholz P. 2000. Katalog der Flechten und flechtenbewohnenden Pilze Deutschlands. Schriftenreihe Vegetationskunde 31: 1-298.

Søchting U., Alstrup V. 2007. Danish Lichen Checklist. Ver. 2. Available at http://www.bi.ku.dk/lichens/ dkchecklist/ [date of exploration: 2 June 2009].

Sparrius L. B. 2002. Discovery of apothecia confirms generic position of Fellhanera gyrophorica. Lichenologist 34 (1): 86 .

Sparrius L. B. 2003. Contribution to the lichen floras of the Białowieża Forest and the Biebrza Valley (Eastern Poland). Herzogia 16: 155-160.

Suija A., Leppik E., Randlane T., Thor G. 2007. Lichens and lichenicolous fungi. Folia Cryptog. Estonica 43: 73-76.

Sulma T., Fałtynowicz W. 1988. Materiały do rozmieszczenia porostów z rodziny Parmeliaceae w Polsce. Acta Mycol. 23 (1): 107-123.

Szczepańska K. 2008. Antropogeniczne przemiany bioty porostów Masywu Śnieżnika i Gór Bialskich. Acta Botanica Silesiaca. Monographiae 4: 1-291.

Szymczyk R., Kukwa M. 2008. Nowe dane do rozmieszczenia porostów Wysoczyzny Elbląskiej z historycznych zbiorów prof. T. Sulmy. Fragm. Flor.. Geobot. Polonica 15 (2): 289-297.

Tucker S. C., Ryan B. D. 2006. Revised Catalog of Lichens, Lichenicoles, and Allied Fungi in California. Constancea 84. University and Jepson Herbaria, California Lichen Catalog. Available at http:// ucjeps.berkeley.edu/constancea/84/index.html [date of exploration: 2 June 2009]. 
Vězda A., Liška J. 1999. Katalog Lišejníků České Republiky. Institute of Botany, Academy of Sciences of the Czech Republic, Průhonice, 283 pp.

Vitikainen O., Ahti T., Kuusinen M., Lommi S., Ulvinen T. 1997. Checklist of lichens and allied fungi of Finland. Norrlinia 6: 1-123.

Wolseley P. A., Aguirre-Hudson B., McCarthy P. M. 2002. Catalogue of the lichens of Thailand. Bull. Nat. Hist. Museum London (Bot.) 32 (1): 13-59.

Nowe notowania porostów z polskich wyżyn

Streszczenie

W pracy przedstawiono pięć gatunków porostów (Bacidia pycnidiata, Fellhanera gyrophorica, Leucocarpia biatorella, Parmotrema perlatum i Punctelia ulophylla), które występowały na sześciu nowych stanowiskach zlokalizowanych w Polsce Środkowej. Badane materiały zdeponowane są w zielniku KTC.

Wśród stwierdzonych gatunków, Bacidia pycnidiata, Leucocarpia biatorella i Punctelia ulophylla są porostami zanotowanymi w Polsce Środkowej po raz pierwszy. Jednocześnie stanowisko Bacidia pycnidiata jest trzecim stwierdzonym stanowiskiem w Polsce. Gatunkami nowymi dla Gór Świętokrzyskich są Bacidia pycnidiata i Leucocarpia biatorella. 